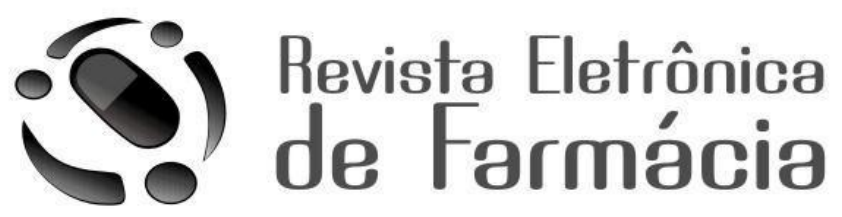

REF-ISSN1808-0804 Vol.XI (2),37-54, 2014.

\title{
METHODS USED IN EVALUATION OF THE SUN PROTECTION FACTOR OF SUNSCREENS
}

\author{
MÉTODOS USADOS NA AVALIAÇÃO DO FATOR DE PROTEÇÃO DE \\ PROTETORES SOLARES
}

MÉTODOS UTILIZADOS EN EVALUACIÓN DEL FACTOR DE LA PROTECCIÓN SOLAR DE PROTECTORES SOLARES Stefani Garcia Rezende, João Gabriel Dourado, Fernando Miguel Amorim de
Lino, Daniela Cristina Vinhal, Elton C Silva, Eric de Souza Gil

Received on 25/10/2013, Accepted on 31/01/2014.

ABSTRACT: The main way of analyzing the effectiveness of a sunscreen is through the sun protection factor (SPF) which can be obtained through in vivo and/or in vitro methodologies. This paper aims to review these methodologies and evaluate the effectiveness of in vitro tests, focused in spectrophotometry ultraviolet, compared to traditional in vivo methods.

DESCRIPTORS: Methodology, Sun Protection Factor, Spectrophotometry.

RESUMO: A principal forma de análise da eficácia de um filtro solar é através do fator de proteção solar (FPS) que pode ser obtido através de metodologias in vivo e/ou in vitro. Este trabalho tem como objetivo revisar estas metodologias e avaliar a eficácia dos testes in vitro, com foco na espectrofotometria ultravioleta, em relação aos tradicionais métodos in vivo.

PALAVRAS-CHAVE: Fator de Proteção Solar, Testes in vitro, Espectrofotometria Ultravioleta.

RESUMEN: La forma principal de analizar la eficacia de un protector solar es a través del factor de protección solar (FPS) que se puede obtener a través de metodologías in vivo $\mathrm{y} / \mathrm{o}$ in vitro. Este trabajo tiene como objetivo revisar estas metodologías y evaluar la eficacia de los testes in vitro, centrándose en espectrofotometría ultravioleta, en relación con los métodos tradicionales en vivo.

PALABRAS-CLAVE: Factor de protección, Testes in vitro, Espectrofotometría Ultravioleta 
REZENDE, S. G.; DOURADO, J. G.; LINO F. M. A; VINHAL, D. C.; SILVA, E. C.; GIL, E. S.

REF-ISSN1808-0804 Vol.XI (2),37-54, 2014.

\section{INTRODUCTION}

The excess radiation that reaches the skin excites the existing chromophores, promoting their interaction with molecular oxygen, resulting in oxidative stress caused by an exacerbated increase of reactive oxygen species (ROS). In general, the action of these ROS promotes a reduction of endogenous levels of antioxidants, lipid peroxidation, DNA breakage, enzyme inactivation and consequently, the pathogenesis and photoaging of $\operatorname{skin}^{(1)}$.

Response of the organism to sunlight radiation is cumulative, causing changes in collagen and elastic fibers, loss of adipose and subcutaneous tissue and photocarcinogenesis. The harmful effects can be divided into acute and chronic. The acute are sunburn, druginduced photosensitivity and exacerbation of diseases such as lupus erythematosus, vitiligo and herpes simplex virus, among others. Chronic effects are characterized by photoaging, immunosuppression and photocarcinogenesis, in addition to pigmented lesions such as actinic keratosis $^{(2)}$.

A survey by the Brazilian Society of Dermatology (BSD) $)^{(3)}$ in 2010 revealed that there is a nationwide incidence of skin cancer around $11.12 \%$ of a total of 32,428 attendances. Of the total, whiteskinned people accounted for $14.08 \%$ of cancers in the majority of basal cell carcinomas. Very noteworthy data also revealed that men would be most affected by photocarcinogenesis and these were exposed to the sun more often and without protection $37.87 \%$ of cases compared with women, $20.76 \%$ of cases of exposure radiation without protection ${ }^{(3)}$.

Due these data, people now are using more frequently products to protect themselves from sun, meanly sunscreens. However, it is necessary that a very efficient sunscreen substance be used in the cosmetic formulation. Therefore, in order to check such efficiency, many methods have been proposed.

\section{SUNSCREENS}

The spectrum of sunlight radiation is composed mainly by infrared (IR), visible (VIS) and ultraviolet (UV) radiation, which reach the planet's surface at a rate of approximately $50 \%$ IR, $45 \%$ VIS and $5 \% \mathrm{UV}^{(4)}$. It includes wavelengths between 200 and 400 nanometers (1 $\mathrm{nm}=10^{-9} \mathrm{~m}$ ) and is common to separate UV radiation in UVA (320$400 \mathrm{~nm})$, UVB (290-320 nm) and UVC $(200-290 \mathrm{~nm})^{(5)}$. Radiation shorter than $290 \mathrm{~nm}$, like UVC, practically does not reach the surface, being 
REZENDE, S. G.; DOURADO, J. G.; LINO F. M. A; VINHAL, D. C.; SILVA, E. C.; GIL, E. S.

REF-ISSN1808-0804 Vol.XI (2),37-54, 2014.

absorbed by the stratospheric ozone layer $^{(6)}$.

UVB radiation is highly energetic and can be absorbed by the glass. It is responsible for acute and chronic damage to the skin, such as stains, burns (redness and blisters), scaling, skin cancer; epidermal DNA damage and Langerhans cells by suppressing the immune response ${ }^{(7)}$.

UVA rays, in turn, are the most abundant and cross the most common glasses $^{(8)}$. Because they have larger wavelengths, they are less energetic and from 600 to 1000 times less erythematogens, penetrating deeper into the dermal layer with possible cumulative damage to the structural components of the $\operatorname{skin}^{(9)}$.

To minimize the deleterious effects of ultraviolet radiation, public education on photoprotective measures should be continued. The most effective one clearly is complete avoidance of sun exposure during its peak ultraviolet radiation (10 a.m.-4 p.m. $)^{(10)}$. Such action should be accompanied by the use of appropriate clothing, wide-brimmed hat, sunglasses, and broad-spectrum sunscreen to achieve the optimal protection.

Sunscreens are chemicals with properties to absorb, reflect and scatter the radiation incident on the skin $^{(11)}$. These active compounds can be organic or inorganic and theirs combination within a complex vehicle matrix will provide a protection against UVA and UVB radiation ${ }^{(12)}$.

Furthermore, they must be stable in human skin and heat, photostable under the sunshine to ensure protection for several hours; and they must not be irritating, sensitizing or phototoxic. They must cover and protect the surface of the skin without penetrating it, avoiding systemic exposure; they should be waterproof, tasteless, odorless and colorless; and compatible with cosmetic formulations ${ }^{(13)}$.

The inorganic powders filters are inert, opaque, insoluble in water and fatty material ${ }^{(13)}$. The most commonly used are zinc oxide ( $\mathrm{ZnO})$ and titanium dioxide $\left(\mathrm{TiO}_{2}\right)$, and others such as cerium, talc, kaolin and zirconium $^{(14)}$. They form a physical barrier on the skin, reflecting and/or scattering UV light.

Organic filters act, basically, in the absorption of UV radiation, but can also reflect and scatter light at the same time ${ }^{(13-14)}$. They are generally aromatic compounds conjugated with an electron releasing group in the ortho or para position of the aromatic ring. These groupings, called chromophores, are responsible for the absorption of incident radiation $^{(9,13,14,15)}$.

Regulatory agencies in Europe and in Brazil treat sunscreens as cosmetics, so legislation is a faster process; however, in the U.S., the 
REZENDE, S. G.; DOURADO, J. G.; LINO F. M. A; VINHAL, D. C.; SILVA, E. C.; GIL, E. S. REF-ISSN1808-0804 Vol.XI (2),37-54, 2014.

substances in sunscreens are treated as drugs and can be registered only after a minimum of five years of existence in the market of five foreign countries. After the commercial experience, must be submitted efficacy data and safety ${ }^{(16)}$.

Besides the efficacy and safety there are some issues that diminish the achievement of effective and lasting action of sunscreens ${ }^{(17)}$, such as using inappropriate amounts of sunscreen, frequency of application, reapplication after swimming, missed skin sites, and levels of sun protection provided $^{(18-19)}$

\section{DETERMINATION OF THE SUN PROTECTION FACTOR}

Early attempts to categorize sunscreens simply based on sun protection factor have proven to be inadequate because other factors also play clinically significant roles in the overall effectiveness of sunscreens. The distinction between the various active ingredient compounds becomes important at a basic science level because these products vary in their absorption spectrum and water resistance ${ }^{(20)}$, which can be solve using a combination between the different filters, chemical and physical in the same formulation.

The proof of sunscreen products efficacy is of high importance for the protection of public health as the UVB fraction of solar radiation is the main contributor to skin sunburn, immunosuppression and skin cancer $^{(21)}$. The primary method of evaluating the efficacy of sunscreens has been through the measurement of the SPF for $U_{V B}{ }^{(20)}$ e UVAFP for $U_{V A}{ }^{(5,22)}$, which can be performed by tests in vivo and/or in vitro.

However, there are many factors affecting the determination of sun protection factor values, as for example, the use of different solvents in which the sunscreens are dissolved, the combination and concentration of the sunscreens, the type of emulsion, the effects and interactions of vehicle components used in the formulation, the interaction of the vehicle with the skin, the addition of other active ingredients, the $\mathrm{pH}$ system and the emulsion rheological properties, among other factors, which can increase or decrease UV absorption of each sunscreen ${ }^{(23)}$.

The assay of sunscreen agents in commercial products is important for quality control purposes and for checking their conformance to the existing legislation. In addition, in order to ensure an adequate photoprotective action during usage, the stability of the sunscreen in the finished product needs to be determined ${ }^{(24)}$.

\section{In vivo UVB methodology}


REZENDE, S. G.; DOURADO, J. G.; LINO F. M. A; VINHAL, D. C.; SILVA, E. C.; GIL, E. S.

REF-ISSN1808-0804 Vol.XI (2),37-54, 2014.

The methodologies in vivo currently recommended are Australian standard $^{(25)}$; COLIPA International Sun Protection Factor Test Method, most recently updated in 2009 used in European countries ${ }^{(26)}$ and FDA commonly used in the United States of America, and they are ideally determined by phototesting in human volunteers $^{(5,23)}$.

Until the 1950s, sunscreens were analyzed only by a spectrophotometric absorption curve without quantitative analysis. At that time, Schulze and Mansur (27-28) initiated comparative studies of sunscreens, creating the sun protection factor (SPF) performing tests on humans to determine the minimum erythematogenic dose (MED). This method calculates the ratio of the duration of UVB radiation exposure needed to elicit an erythematic response in sunprotected skin versus non sunprotected skin (Equation $1^{)(5,15,28,29)}$. The resulting value is the SPF of the product.

$$
S P F=\frac{M E D_{p}}{M E D_{u}}
$$

(Equation 1)

Where:

$M D_{p}$ - Minimal Erythematogenic Dose for protected skin;

$\mathrm{MED}_{u}$ - Minimal Erythematogenic Dose for unprotected skin.

Minimal erythemal dose (MED) is a measure of the amount of energy per unit area $\left(\mathrm{J} / \mathrm{cm}^{2}\right)$ required to cause minimal erythema. It must be determined empirically over many days so as not to cause excessive burning to the skin of the subjects as a result of repeated exposure ${ }^{(15,28,29)}$.

The determination the SPF made by in vivo methods ${ }^{(16)}$, use twenty healthy individuals of both sexes with an average sensitivity to UVB. It is placed in the back half of each individual $(0.3 \mathrm{~m} \times 0.3 \mathrm{~m})$ sunscreen $\left(150 \pm 15 \mathrm{mg} / 100 \mathrm{~cm}^{2}\right)$ in $4 \mathrm{~cm}^{2}$, also leaving an uncovered part (surface test), separated by a tape of $1 \mathrm{~cm}$ wide. A lamp of $300 \mathrm{w}$ irradiated UV light for twenty minutes after application. The time of erythema formation is observed and the FPS is obtained after the calculations, which is based on the quantification of the Minimal Erythematogenic Dose (MED) in relation to the biological effect of UVB irradiation ${ }^{(30)}$. The standard used by the FDA is a formulation containing $8 \%$ homosalate, which gives an SPF of $4.47(16)$. For COLIPA the standard formula contains $2.7 \%$ octyl $p$ methoxycinnamate (SPF $3.7 \quad \pm$ $0.3)^{(31)}$. The final average found cannot be less than the SPF stated on the product packaging by the manufacturer and the variation of the twenty values found cannot be greater than $5 \%{ }^{(32)}$.

The COLIPA methodology $y^{(33)}$ used at least ten and not more than twenty volunteers, depending on the desired statistical significance. Since, 
REZENDE, S. G.; DOURADO, J. G.; LINO F. M. A; VINHAL, D. C.; SILVA, E. C.; GIL, E. S. REF-ISSN1808-0804 Vol.XI (2),37-54, 2014.

as in the previous method, the FPS is also obtained from the average of the measurements, the parameters allow for the approval of a variation $\pm 20 \%$ from the stated SPF.

However, for Pissavini ${ }^{(34)}$ high SPF values are more difficult to measure. A high SPF normally leads to a greater uncertainty also in the final in vivo result, due to the biological variations of the volunteers. The in vivo method of measuring sunscreen efficacy has its shortcomings. Primarily, the SPF measures the ability to block the skin's response to UVB radiation and ignores UVA radiation and despite of the fact that the SPF does not provide information regarding the ability of sunscreens to withstand aqueous conditions, such as sweating and swimming ${ }^{(20)}$, there is a new legislation since 2012 that requires the determination of water resistance of the sunscreens ${ }^{(5)}$.

\section{In vivo UVA methodology}

The main in vivo method is Persistent Pigment Darkening (PPD) as recommended by the Japan Cosmetics Industry Association (JCIA), standardized and published in
$1996^{(35)}$. It is based on the response of delayed or persistent pigmentation of the skin against UVA (320-400 nm) after an exposure period of 2 to 4 hours $^{(22,35)}$. This response is a biological reaction, which develops after irradiation of the skin by a pure UVA simulated sunlight source. The PPD method just occurs after a preliminary identification of the IPD (Immediate Pigment Darkening). The IPD is a transient darkening of the skin observed after UVA exposure. It includes change in the structure of melanocytes and keratinocytes, as well as modification of preexisting melanin (36).

The darkening of the skin is one of the more immediate responses, and is considered stable and reproducible. Thus, the PPD corresponds to the ratio of UVA doses required to produce the response with and without sunscreen on the skin. JCIA established that the indication of UVA protection in sunscreen products label must be made by categories, not numbers, according Table $\mathrm{I}^{(22,35)}$. This method was accepted by the European Union and Japan and has also been recommended by the FDA and ANVISA ${ }^{(5,37)}$.

Table 1 - Method validated by JCIA to declare the UVA protection and its correlation with the values of determined PPD.

\begin{tabular}{lcccc}
\hline PPD values & $\mathbf{0 - 2}$ & $\mathbf{2 - 4}$ & $\mathbf{4 - 8}$ & $\mathbf{8 8}$ \\
\hline Indication of Protection in UVA & - & + & ++ & +++ \\
Level of Protection & Without & Low & Moderate & Good \\
\hline
\end{tabular}


REZENDE, S. G.; DOURADO, J. G.; LINO F. M. A; VINHAL, D. C.; SILVA, E. C.; GIL, E. S.

REF-ISSN1808-0804 Vol.XI (2),37-54, 2014.

The method has been recognized by these various countries or regulatory agencies with some minor differences and was standardized by the International Organization for Standardization (ISO) $)^{(38)}$, although some studies concluded that only the PPD method is insufficient to determine the degree of protection against UVA radiation of sunscreen products. This happens due to the fact that this radiation needs 18 to 24 hours to cause pigmentation on the skin, unlike UVB rays, which takes 2 to 4 hours. It has been recognized that both erythema and persistent pigmentation responses require relatively high exposure doses of UVA $\left(10-20 \mathrm{~J} / \mathrm{cm}^{2}\right)$ and high intensity sources for dosing test sites ${ }^{(39)}$.

Moreover, the in vivo method is expensive and time consuming, factors that make it difficult to be adopted in routine quality control ${ }^{(40)}$. As a consequence, a lot of efforts have been devoted to the development of in vitro techniques for assessing the photo-protection ability of sunscreen products. These methods produce estimates of protection factors, which correlate with the results obtained with in vivo photo testing of human subjects.

\section{In vitro UVB methodology}

Regulatory agencies such as the FDA and COLIPA make in vivo testing on human subjects, using an erythemal endpoint to determine the SPF of a topical sunscreen. These are costly and time-consuming tests which are not practical for routine product evaluation. That being said, there are still many questions about both the scientific accuracy and reproducibility of in vivo measurements. It is not statistically valid to test only a very small number of volunteers and also be potentially hazardous to subjects ${ }^{(34,41)}$. So, both ethical and legal considerations point to the wider acceptance over time of in vitro measurement techniques

The in vitro test is based on the physical and optical determination of the reduction of the energy in the UV range, through a film of product which has previously been spread onto an adequate substrate ${ }^{(34)}$. They are in general of two types: methods which involve the measurement of absorption or the transmission of UV radiation through sunscreen product films in quartz plates or biomembranes; and methods in which the absorption characteristics of the sunscreens agents are determined based on spectrophotometric analysis of dilute solutions ${ }^{(23)}$.

The high variability of in vitro results suggests that main attention should be focused on substrate 
REZENDE, S. G.; DOURADO, J. G.; LINO F. M. A; VINHAL, D. C.; SILVA, E. C.; GIL, E. S.

REF-ISSN1808-0804 Vol.XI (2),37-54, 2014.

selection simulating the human skin surface and homogenous product application $^{(21)}$. The substrate plate is the material on which the sun care product is applied. It must be UVtransparent, non-fluorescent (i.e., no detectable fluorescence when exposed under UVR and measured with the spectrophotometer), photostable and inert towards all ingredients of the preparations to be tested ${ }^{(33)}$. It also must have optical and physicalchemical properties close to those of the $\operatorname{skin}^{(42)}$. Thus the in vitro test of the sunscreen is based on absorbance (calculated from transmittance) or reflectance measurements through a thin film of sunscreen spread over roughened substrate, before and after exposure to a controlled dose of UV radiation from a defined source ${ }^{(33)}$.

At present, however, a standard material has not yet been defined. The most commonly adopted substrates are: roughened polymethylmethacrylate (PMMA) plates $^{(33)}$, Transpore ${ }^{\circledR(43)}$, VitroSkin ${ }^{\circledR(44)}$, roughened quartz plate ${ }^{(45)}$ and Teflon (PTFE) ${ }^{(40)}$.

The attenuated UVB intensity, using different UV light sources, is detected radiometrically and transformed to real SPF value by means of a calibration curve based on diffuse spectroscopy transmission or measurements of UV transmission through a thin film product applied on various UV-transparent substrates, which is based on an extensive number of measurements performed. The spectral transmittance of a sunscreen in the ultraviolet spectral range can be used to predict an in vitro SPF value based on standard erythematic and solar data(41). The in vitro SPF is calculated as follows (Equation 2) $^{(43,46) \text { : }}$

$$
S P F_{\text {iviviro }}=\frac{\int_{290 \mathrm{~nm}}^{400 \mathrm{~nm}} E_{\lambda} \times I_{\lambda} \times d_{\lambda}}{\int_{200 \mathrm{~nm}}^{400 \mathrm{~m}} E_{i} \times I_{\lambda} \times T_{\lambda} \times d}
$$

(Equation 2)

Where:

$\mathrm{E}_{\Lambda}$ - erythema action spectrum;

$I_{\Lambda}$ - spectral irradiance received from the UV source;

$T_{\Lambda}$ - spectral transmittance of the sample;

$d_{\wedge}$ - wavelength step $(1 \mathrm{~nm})$.

The two standardized functions, $E_{\Lambda}$ and $I_{\Lambda}$, describe the relative sensitivity of erythema to individual wavelengths and the spectral distribution of sunlight as it reaches the earth's surface ${ }^{(43,46)}$.

With regard to the instrumentation, the absorption spectrum is the most relevant parameter for define the protective performance of sunscreen products $^{(41)}$.

Mansur $^{(28)}$ developed a very simple mathematical equation which substitutes the in vitro method proposed by Sayre ${ }^{(47)}$, utilizing UV spectrophotometer with the following Equation 3: 
$S P F_{\text {espectroplotometric }}=C F \times \sum_{290 \mathrm{~nm}}^{320 \mathrm{~nm}} E_{\lambda} \times I_{\lambda} \times A$

Where:

(Equation 3)

EE - erythemal effect spectrum on the wavelength $(\Lambda)$;

I - solar intensity spectrum on the wavelength $(\Lambda)$;

Abs - absorbance of sunscreen product on the wavelength $(\Lambda)$;

$\mathrm{CF}$ - correction factor $=10$.

It was determined so that a standard sunscreen formulation containing $8 \%$ homosalate presented a SPF value of 4 , determined by UV spectrophotometry ${ }^{(28)}$.

For Mansur ${ }^{(28)}$, when evaluating a sunscreen by spectrophotometry, it is not enough to identify the calibration curve. One should also identify the height, width and location of the calibration curve obtained in the ultraviolet spectrum to perform the calculation of the SPF.

Studies conducted by Bendová(21), demonstrated that in general, all the in vitro methods tend to overestimate the SPF value for low protection sunscreens and underestimate the SPF for sunscreens with medium and high protection, namely for products with SPF over 30 . This underestimation in vitro might be attributed to differences in particles distribution within the human skin relief in vivo and the plain surface of the artificial substrate in vitro.

Studies made by Heinrich ${ }^{(48)}$, demonstrated that the correlation between in vitro and in vivo data depends on the quantity of applied product, making it difficult to obtain a 1:1 correspondence. Other parameters that affect the correlation are: type of formula, type of substrate, possible chemical reaction between substrate and sunscreen, instrument used for measurements. For this reason in vitro SPF testing can be successfully used for directional indications of protection, but it cannot be considered to be absolute and is not a substitute for in vivo testing to establish product efficacy claims. Currently studies showed that for the development of sunscreens formulations, in vitro methodologies could be useful in the selection of the best choice to be tested with volunteers with speed and lower cost ${ }^{(49)}$.

For Bendová(21), preference should be given to in vitro testing methods in relation to the SPF COLIPA testing method in vivo as a way to ratify the ethical concern and for screening purposes, like a way to minimize risks related to UV exposure of human subjects during a sunscreen product development ${ }^{(30)}$. Furthermore, in vitro methods are attracting increasing attention because they are more rapid, less expensive and circumvent the involvement of human volunteers with the related ethical problems $^{(50)}$.

A relevant, reproducible and accurate in vitro method has not been 
REZENDE, S. G.; DOURADO, J. G.; LINO F. M. A; VINHAL, D. C.; SILVA, E. C.; GIL, E. S.

REF-ISSN1808-0804 Vol.XI (2),37-54, 2014.

developed yet, but groups of the European Committee for Standardization (CEN) and the International Organization for

\section{In vitro UVA methodology}

Increasing concern with the effects on the UVA radiation has led to the development of broad-spectrum sunscreens, which attenuate exposure effectively and raised the need for official methods to properly evaluate the level of protection offered by sunscreens products against UVA. The FDA proposes a connection between in vivo and in vitro methods to evaluate UV protection and to determine the effectiveness of sunscreens with UVA action ${ }^{(16)}$.

The COLIPA "In Vitro Sun Protection Methods" group was given the assignment to develop in vitro measures of UVA wavelength, correlated with in vivo measures of the same sample ${ }^{(26)}$. The test COLIPA 'In Vitro Sun Protection Methods' group is based on the measurement of UV radiation transmission through a thin film of sunscreen sample spread on a UV-transparent roughened substrate, before and after exposure to a controlled dose of UV from a defined source of solarsimulated radiation (SSR). The data obtained are compared with the action spectrum for in vivo Persistent Pigment Darkening (PPD) with
Standardization (ISO) are developing frequent studies for validation according with the Standardization Mandate $\mathrm{M} / 389 \mathrm{EN}^{(46)}$.

emission spectrum of the filtered solar simulator used for the in vivo PPD test (in vitro UVA Protection Factor UVAPF) $)^{(26,46)}$.

There are also other methods in vitro, not so specific, developed for assessment of UVA protection, but which may contribute, in conjunction with in vivo methods, to determine the effectiveness of sunscreens. These methods are the critical wavelength(14); calculating the ratio UVA/UVB ${ }^{(43)}$; method regulated by the Australian document AS/NZS 2604:1998(25), relating the result obtained with PPD in vitro and in vivo UVB protection.

The Critical Wavelength (CW) method is based on the use of the spectrophotometer with an integrating sphere at the range of $290-400 \mathrm{~nm}$. The wavelength at which the summed absorbance reaches $90 \%$ of total absorbance is defined as the critical wavelength and is considered to be a measure of the breadth of the sunscreen protection (Equation

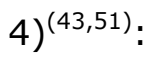

$$
\int_{290 n m}^{\lambda c} A_{\lambda} \times d \lambda=0,9 \int_{290 n m}^{400 n m} A_{\lambda} \times d \lambda
$$

(Equation 4)

Where: 
$A_{\wedge}$ - absorbance of the product in the defined wavelength; $\mathrm{nm})$.

$d_{\wedge}$ - wavelength increment (1

So, sunscreen products are then classified as broad-spectrum having a significant part of their absorbance in

SPECTROANALYTICAL METHODS

\section{Absorption Spectroscopy in the UV-Visible}

The absorption of ultraviolet or visible radiation usually results from the excitation of bonding electrons. As a result, the wavelengths of absorption peaks can be correlated with the types of connections in the species under study. Thus, applications of spectroscopy in the UV-visible absorption are important for the quantitative determination of compounds containing absorbing groups (chromophores) like those present in sunscreens. Such quantification is performed by means of light through measures of absorbance (A) or transmittance $(\mathrm{T})^{(52)}$.

Many sunscreens are translucent materials, which diffuse incident light. A ray of light incident onto a sunscreen sample will often be scattered. Light that is not transmitted is reflected or absorbed $^{(41)}$. For translucent samples, the radiation intensity is strongest in the UVA, when the critical wavelength is longer than $370 \mathrm{~nm}$. This technique studied by the COLIPA and by Toiletry \& Fragrance Association of South Africa (CTFA-SA) groups was regulated by the FDA on June 17 , $2011^{(37)}$.

proximity to the regular transmitted direction. Opaque samples will produce an intensive pattern that approaches a uniform, hemispherical distribution. The ratio of the total transmitted light to the total incident light is known as the transmittance, a measurable quantity. Total hemispherical transmittance is measured by the use of an integrating sphere to collect the light scattered at all angles ${ }^{(26,41)}$.

The in vitro efficacy of photoprotective molecules can be evaluated with diffuse reflectance spectrophotometer to an integrating sphere. The spectrophotometric method is based on the correlation between the energy of diffuse reflectance and absorption coefficients and dispersion of a sample. The records of the spectrophotometric transmittance values can be performed at intervals of wavelength in a range of $1 \mathrm{~nm}^{(49)}$.

However, the ability of a spectrophotometer to measure transmission or protection factors accurately is limited by the sensitivity of the instrument. The maximum 
REZENDE, S. G.; DOURADO, J. G.; LINO F. M. A; VINHAL, D. C.; SILVA, E. C.; GIL, E. S.

REF-ISSN1808-0804 Vol.XI (2),37-54, 2014.

measured absorbance should be within $90 \%$ of the dynamic range of the device used. As a consequence, the spectroradiometer must be designed for efficient stray-light rejection $^{(26)}$.

\section{Fluorescence Spectroscopy}

The fluorescence spectroscopy is an optical method in which the analyte molecules are excited by photon absorption, originating species whose emission spectrum provides information for qualitative and quantitative analysis. When the light of an appropriate wavelength is absorbed by a molecule, the electronic state of the molecule changes from the ground state to one of many vibrational levels in one of the excited electronic states. With the molecule in this excited state, relaxation can occur via fluorescence resulting in the emission of light ${ }^{(52)}$.

Fluorescence has a short lifetime ( $\sim 10-8 \mathrm{sec})$, the wavelength of the light emitted is dependent on the energy gap between the ground state and the singlet excited state. The fluorescence process could be written as shown in Equation $5^{(53)}$ :

$$
E_{f u o r}=E_{a b s}-E_{v i b}-E_{\text {solv.relax. }}
$$

(Equation 5)

Where: light;

Efluor - energy of the emitted
Eabs - energy of the light absorbed by the molecule during excitation;

Evib - energy lost by the molecule from vibrational relaxation.

The $E$ solv.relax term arises from the need for the solvent cage of the molecule to reorient itself in the excited state and then again when the molecule relaxes to the ground state. As can be seen from Equation 5, fluorescence energy is always less than the absorption energy for a given molecule. Thus, the emitted light is observed at longer wavelengths than the excitation ${ }^{(52)}$.

Nowadays, there are many sunprotection cosmetics incorporating physical UV filters as active ingredients; however, there are no official methods to determine these kinds of compounds in sunscreen cosmetics $^{(54)}$. Thus, the fluorescence spectroscopy would help in identifying these molecules that act as physical filters in sunscreens. The technique of fluorescence allows the estimation of the protection factor (SPF) of the physical filter without the sample preparation, beyond the identification of other metals that may be present $^{(54)}$.

Studies by Diffey and Rhodes ${ }^{(55)}$ showed that in addition to quantifying physical sunscreen agents, fluorescence spectroscopy can also dispense other substances in the formulation. Studies have suggested the feasibility of using fluorescence 
REZENDE, S. G.; DOURADO, J. G.; LINO F. M. A; VINHAL, D. C.; SILVA, E. C.; GIL, E. S.

REF-ISSN1808-0804 Vol.XI (2),37-54, 2014.

spectroscopy as an in vivo quantitative technique to assess sunscreen substantivity in terms of skin surface thickness and/or photoprotection. In other words, this technique can determine the uniformity of the layer of sunscreen on the skin through the emission of light intensity and thus determine the optimal concentration of sunscreens by body region. However, for the vast majority of sunscreens, which produce relatively low levels of autofluorescence, it will be necessary to add suitable fluorescing agents.

Fluorescence spectroscopy can also assist in understanding the

\section{CONCLUSION}

The consequences of UV damage are significant and are affecting a growing portion of the population. Previous methods used to evaluate sunscreens solely using SPF have subsequently proved to be inadequate, because the deleterious consequences of UVA exposure have become known. It is necessary to emphasize the need to develop a methodology effective in vitro, to determine quantitatively the susceptibility of optical products, since processes of the excited state of sunscreen when in contact with human skin, such as lifetime of the excited state, quantum yields and rates of radioactivity and nonradioactivity of the organic components $^{(56)}$. These may occur through the transfer of load and interactions involving hydrogen bonds formed within the molecule or solvent, resulting in conformational changes $^{(57)}$. In general, the use of fluorescence spectroscopy helps identify the effects of processes occurring after excitation of sunscreens ${ }^{(56)}$.

the in vivo method determines qualitatively the UVAPF limited to only the appearance of erythema on the skin of volunteers. In summary, in vitro test methods can give meaningful information about UVA protection, but there has not yet been a complete procedure that has been correlated with in vivo test results in a manner for wide scale reliable use and reproducible results. Efforts are underway by a number of research goups to help reduce the complex variables to a single reliable test method.

\section{REFERENCES}

1. Halliwell B. Role of free radicals in the neurodegenerative diseases: therapeutic implications for antioxidant treatment. Drugs Aging. 2011;18(9):685716. 
REZENDE, S. G.; DOURADO, J. G.; LINO F. M. A; VINHAL, D. C.; SILVA, E. C.; GIL, E. S.

REF-ISSN1808-0804 Vol.XI (2),37-54, 2014.

2. Lautenschlager S, Wulf HC, Pittelkow MR. Photoprotection. Lancet. 2007;370(9586):528-537.

3. Sociedade Brasileira de Dermatologia (SBD) [Internet]. Relatório da Campanha Nacional de Prevenção ao Câncer de Pele; 2010 [cited 2013 sept 25]. Available from: http://sbd.tempsite.ws/capele/gestao/distribuicao fotoprotecao sexo.asp?uf=NULL \&cidade $=$ NULL\&servico $=$ NULL\&campanha $=3$

4. Adad MCBT. Determinação do fator de proteção solar "in vitro" [thesis]. Porto Alegre: Pontifícia Universidade Católica do Rio Grande do Sul/PUCRS; 2007. $104 p$.

5. Ministério da Saúde; Agência Nacional de Vigilância Sanitária (ANVISA). Resolução No 30, de 01 de junho de 2012 - Regulamento Técnico Mercosul sobre Protetores Solares em Cosméticos (D.O.U. 25/05/2012). Brasília (Brasil): Ministério da Saúde; 2012.

6. Deccache DS. Formulação dermocosmética contendo DMAE glicolato e filtros solares: desenvolvimento de metodologia analítica, estudo de estabilidade e ensaio de biometria cutânea [thesis]. Rio de Janeiro: Universidade Federal do Rio de Janeiro/UFRJ; 2006.

7. Heenen M, Giacomoni PU, Golstein P. Individual variations in the correlation between erythemal threshold, UV-induced DNA damage and sun-burn cell formation. J Photochem Photobiol B. 2001;63(1-3):84-87.

8. Agência USP de Notícias [Internet]. Raios ultravioleta A têm ação direta e indireta sobre DNA; 2012 [cited 2013 sept. 27]. Available from: http://www.usp.br/agen/?p=116458

9. Oliveira AGC, Dutra EA, Santoro MIRM, Kedor-Hackmann ERM. Protetores Solares, Radiações e Pele. Cosmet Toilet. 2004;16(2):68-72.

10. Lim HW, Cooper K. The health impact of solar radiation and prevention strategies: report of the environment council, American Academy of Dermatology. J Am Acad Dermatol. 1999;41(1):81-99.

11. Ministério da Saúde; Agência Nacional de Vigilância Sanitária (ANVISA). Resolução de Diretoria Colegiada No 47, de 16 de março de 2006. (D.O.U. 20/03/2006). Brasília (Brasil): Ministério da Saúde; 2006.

12. Moyal D. The development of efficient sunscreens. Indian J Dermatol Venereol Leprol. 2012;78(7):31.

13. Ribeiro C. Cosmetologia aplicada a Dermocosmética. 2nd ed. São Paulo: Pharmabooks; 2010.

14. Shaath NA. The encyclopedia of ultraviolet filters. 1st ed. New York: Allured Publishing Corporation; 2007.

15. Wolf R, Wolf D, Morganti P, Ruocco V. Sunscreens. Clin Dermatol. $2001 ; 19(19): 452-459$. 
16. Department of Health and Human Services; Food and Drug Administration (FDA). 21 CFR Parts 347 to 352 - Sunscreen drug products for Over-the-Counter Human use; proposed amendment of final monograph. United States of America; 2007.

17. Nicol I, Gaudy C, Gouvernet J, Richard MA, Grob JJ. Skin protection by sunscreens is improved by explicit labeling and providing free sunscreen. J Invest Dermatol. 2007;127(1):41-48.

18. Reich A, Harupa M, Bury M, Chrzaszcz J, Starczewska A. Application of sunscreen preparations: a need to change the regulations. Photodermatol Photoimmunol Photomed. 2009;25(5):242-244.

19. Yang HP, Chen K, Ju M, Chang BZ, Wang LY, Gu H. A study of the way in which dermatologists and photosensitive patients apply sunscreen in China. Photodermatol Photoimmunol Photomed. 2009;25(5):245-249.

20. Koshy JC, Sharabi SE, Jerkins D, Cox J, Cronin SP, Hollier Jr. LH. Sunscreens: evolving aspects of sun protection. J Pediatr Health Care. $2010 ; 24(5): 343-346$.

21. Bendová $H$, Krejcí $A$, Kubác $L$, Jírová $D$, Kejlová $K$, Kolárová $H$, et al. In vitro approaches to evaluation of Sun Protection Factor. Toxicol In Vitro. 2007;21(7):1268-1275.

22. Moyal D, Chardon A, Kollias N. Determination of UVA protection factors using the persistent pigment darkening (PPD) as the end point (Part 1). Calibration of the method. Photodermatol Photoimmunol Photomed. 2000;16(6):245-249.

23. Dutra EA, Oliveira DAGC, Kedor-Hackmann ERM, Santoro MIRM. Determination of sun protection factor (SPF) of sunscreens by ultraviolet spectrophotometry. Braz J Pharm Sci. 2004;40(3)381-385.

24. Scalia S. Determination of sunscreen agents in cosmetic products by supercritical fluid extraction and high-performance liquid chromatography. J Chromatogr A. 2000;870(1-2):199-205.

25. Therapeutic Goods Administration (AU) [Internet]. Australian regulatory guidelines for OTC medicines (ARGOM); 2003 [cited 2013 sept 27]. Available from: http://www.tga.gov.au/docs/html/argom.htm

26. The European Cosmetic, Toiletry and Perfumery Association (COLIPA) [Internet]. In vitro method for the determination of the UVA protection factor and "critical wavelength" values of sunscreen products; 2009 [cited 2013 sept 22]. Available from: http://www.cosmeticseurope.eu/publications-cosmetics-europeassociation/guidelines. html?view=item\&id=21

27. Schulze, R. [Some experiments and observations to the usual trade problem of the sunscreens]. Einige Versuche and Bemerkungen Zum problem der Handelsublichen Lichtschutzmittel. Parfu Kosm. 1956;37:310-315.

28. Mansur JS. Breder MNR, Mansur MC d'A, Azulay RD. Correlação entre a determinação do fator de proteção solar em seres humanos e por espectrofotometria. An Bras Dermatol. 1986;61(4)167-172. 
REZENDE, S. G.; DOURADO, J. G.; LINO F. M. A; VINHAL, D. C.; SILVA, E. C.; GIL, E. S.

REF-ISSN1808-0804 Vol.XI (2),37-54, 2014.

29. Bleasel MD, Aldous S. In vitro evaluation of sun protection factors of sunscreen agents using a novel UV spectrophotometric technique. Int J Cosmet Sci. $2008 ; 30(4): 259-270$.

30. The European Cosmetic, Toiletry and Perfumery Association (COLIPA), Toiletry \& Fragrance Association of South Africa (CTFA-SA), Japan Cosmetic Industry Association (JCIA) [Internet]. International Sun Protection Factor (SPF) test method COLIPA, CTFA-SA and JCIA; 2003 [cited 2013 sept 22]. Available from: hatt://www.cosmeticseurope.eu/publications-cosmetics-europeassociation/guidelines. html?view=item\&id $=21$

31. Ministério da Saúde; Agência Nacional de Vigilância Sanitária (ANVISA). Resolução No 237, de 22 de agosto de 2002 - Regulamento técnico sobre protetores solares em cosméticos (D.O.U. 26/08/2002). Brasília (Brasil): Ministério da Saúde; 2002.

32. De Araujo TS, De Souza SO. Protetores solares e os efeitos da radiação ultravioleta. Scientia Plena. 2008;4(11):1148-7.

33. The European Cosmetic, Toiletry and Perfumery Association (COLIPA) [Internet]. Method for the in vitro determination of UVA protection provided by sunscreen products; 2007 [cited 2013 sept 22]. Available from: http://www.cosmeticseurope.eu/publications-cosmetics-europeassociation/guidelines. html?view=item\&id=21

34. Pissavini $M$, Ferrero $L$, Alaro $V$, Heinrich $U$, Tronnier $H$, Kockott $D$, et al. Determination of the in vitro SPF. Cosmet Toilet. 2003;118(6):63-72.

35. Japan Cosmetic Industry Association (JCIA). Measurement Standard for UVA Protection Efficacy. Tokyo: Technical Bulletin. 1996;(21):52.

36. Routaboul C, Denis A, Vinche A. Immediate pigment darkening: description, kinetic and biological function. Eur J Dermatol. 1999;9(2):95-99.

37. Department of Health and Human Services; Food and Drug Administration (FDA). 21 CFR Parts 201, 310, and 352 - Sunscreen Drug Products for Over-theCounter Human Use; Final Rules and Proposed Rules. United States of America; 2011.

38. Moyal D. UVA protection labeling and in vitro testing methods. Photochem Photobiol Sci. 2010;9(4):516-523.

39. Cole $C$. Sunscreen protection in the ultraviolet $A$ region: how to measure the effectiveness. Photodermatol Photoimmunol Photomed. 2001;17:2-10.

40. Garoli D, Pelizzo MG, Bernardini B, Nicolosi P, Alaibac M. Sunscreen tests: correspondence between in vitro data and values reported by the manufacture. J Dermatol Sci. 2008;52(3):193-204.

41. Sprincsteen C, Yurek R, Frazier M, Carr KF. In vitro measurement of sun protection factor of sunscreens by diffuse transmittance. Anal Chim Acta. $1999 ; 380(2-3): 155-164$.

42. Garoli D, Pelizzo MG, Nicolosi P, Peserico A, Tonin E, Alaibac M. Effectiveness of different substrate materials for in vitro sunscreen tests. J Dermatol Sci. 2009;56(2):89-98. 
REZENDE, S. G.; DOURADO, J. G.; LINO F. M. A; VINHAL, D. C.; SILVA, E. C.; GIL, E. S.

REF-ISSN1808-0804 Vol.XI (2),37-54, 2014.

43. Diffey $\mathrm{BL}$, Robson J. A new substrate to measure sunscreen protection factors throughout the ultraviolet spectrum. J Soc Cosmet Chem. 1989;40(3):127133.

44. Diffey BL, Tanner PR, Matts PJ, Nash JF. In vitro assessment of the broadspectrum ultraviolet protection of sunscreen products. J Am Acad Dermatol. 2000;43(6):1024-1035.

45. Akrman J, Kubac L, Bendová H, Jirová D, Kejlova K. Quartz plates for determining sun protection in vitro and testing photostability of commercial sunscreens. Int J Cosmet Sci. 2009;31(2):119-129.

46. Matts PJ, Alard V, Brown MW, Ferrero L, Gers-Barlag H, Issachar N, et al. The COLIPA in vitro UVA method: a standard and reproducible measure of sunscreen UVA protection. Int J Cosmet Sci. 2010;32(1):35-46.

47. Sayre RM, Agin PP, Levee GJ, Marlowe E. A comparison of in vivo and in vitro testing of sunscreening formulas. Photochem Photobiol. 1979;29(3):559-566.

48. Heinrich $U$, Tronnier $H$, Kockott D, Kuckuk R, Heise HM. Comparison of sun protection factors determined by an in vivo and different in vitro methodologies: a study with 58 different commercially available sunscreen products. Int J Cosmet Sci. 2004;26(2):79-89.

49. Velasco MVR, Balogh TS, Pedriali CA, Sarruf FD, Pinto CASO, Kaneko TM, et al. Novas metodologias analíticas para avaliação da eficácia fotoprotetora (in vitro) - revisão. Rev Ciênc Farm Básica Apl. 2011:1(32):27-34.

50. Scalia S, Mezzena M, Bianchi A. Comparative evaluation of different substrates for the in vitro determination of sunscreen photostability: spectrophotometric and HPLC analyses. Int J Cosmet Sci. 2010;32(1):55-64.

51. Wang SQ, Lim HW. Current status of the sunscreen regulation in the United States: 2011 Food and Drug Administration's final rule on labeling and effectiveness testing. J Am Acad Dermatol. 2011;65(4):863-869.

52. Skoog DA, Holler FJ, Nieman TA. Princípios de análise instrumental. 5th ed. Porto Alegre: Bookman; 2002.

53. Pavia DL, Lampman GM, Kriz GS, Vyvyan JR. Introdução à Espectroscopia. 4th ed. São Paulo: Norte-Americana; 2010.

54. Melquiades FL, Ferreira DD, Appoloni CR, Lopes F, Lonni AG, Oliveira FM, et al. Titanium dioxide determination in sunscreen by energy dispersive $\mathrm{X}$-ray fluorescence methodology. Anal Chim Acta. 2008;613(2)135-143.

55. Rhodes LE, Diffey BL. Quantitative assessment of sunscreen application technique by in vivo fluorescence spectroscopy. J Soc Cosmet Chem. 1996;47(2)109-115.

56. Krishnan R, Nordlund TM. Fluorescence dynamics of three UV-B sunscreens. J Fluoresc. 2008;18(1):203-217. 
REZENDE, S. G.; DOURADO, J. G.; LINO F. M. A; VINHAL, D. C.; SILVA, E. C.; GIL, E. S. REF-ISSN1808-0804 Vol.XI (2),37-54, 2014.

57. Beyere L, Yarasi S, Loppnow GR. Solvent effects on sunscreen active ingredients using Raman spectroscopy. J Raman Spectrosc. 2003;34(10):743-750. 